\title{
WALUCHOW ON MORAL OPINIONS AND MORAL COMMITMENTS
}

\author{
Natalie STOLJAR
}

\begin{abstract}
Resumen:
Wil Waluchow al desarrollar su argumento a favor de una concepción propia del common law para las constituciones y para el judicial review, sostiene que existe una distinción de principio entre las "opiniones" de la comunidad o sus "simples preferencias morales" y los compromisos morales "verdaderos" o "auténticos". Además, sostiene que para los jueces es posible identificar los compromisos morales auténticos de una comunidad y aplicar los mismos en la decisión de casos concretos. Si tiene razón, entonces los jueces al decidir casos concretos sobre el alcance de los derechos constitucionales no canalizan sus propios estándares morales subjetivos a las decisiones. En este estudio analizo el uso que hace Waluchow de la distinción entre opiniones morales y compromisos morales. Argumento en primer término que la distinción presupone una metodología descriptiva de la interpretación constitucional, y sugiero que no obstante lo anterior, la metodología de interpretación de los derechos constitucionales es constructiva e implica por parte de los intérpretes y jueces un razonamiento "evaluativo y de justificación" sustantivo. Posteriormente argumento que la distinción entre opiniones morales y compromisos morales no tiene el alcance que pretende y requiere el trabajo de Waluchow y si se modifica, entonces se convierte en una distinción sustantiva. Una concepción sustantiva de autenticidad le genera un problema a Waluchow porque debilita su explicación puramente procedimental de un auto-gobierno democrático.
\end{abstract}

Palabras clave:

Moral; razonamiento judicial; teoría del judicial review; interpretación constitucional; Wil Waluchow. 
Abstract:

In the course of his argument for a common law conception of Constitutional Bills of Rights and judicial review, Wil Waluchow claims that there is a principled distinction to be drawn between a community's 'opinions' or 'mere moral preferences' and its 'true' or 'authentic' moral commitments. Moreover, he argues that it is possible for judges to identify a community's authentic moral commitments and apply them to decide particular cases. If he is right, it is not the case that judges, in making a decision about the application and scope of constitutional rights, are inevitably importing their own subjective moral standards into the decision. I analyze Waluchow's use of the moral opinions -moral commitments distinction. I argue first that the distinction presupposes a descriptive methodology of constitutional interpretation. I suggest however, that the methodology of interpretation in Bills of Rights cases is constructive and involves substantive, 'evaluative and justificatory' reasoning by interpreters and judges. I then argue that the moral opinions-moral commitments distinction either cannot do the work that Waluchow's argument requires, or, if it is modified to do the work, it becomes a substantive distinction. A substantive conception of authenticity creates a problem for Waluchow because it undermines his purely procedural account of democratic self-governance.

Keywords: Morality; Judicial Reasoning, Judicial Review Theory, Constitutional Interpretation, Wil Waluchow. 
Summary: I. Waluchow's Distinction between Moral Opinions and Moral Commitments. II. Methodology and Constitutional Interpretation. III. Inauthentic versus Authentic Moral Commitments. IV. Conclusion. Back to the Question of Judicial Review. V. References.

In A Common Law Theory of Judicial Review, ${ }^{1}$ W. J. Waluchow develops an argument that is designed to block an objection to Bills of Rights and judicial review. The objection is that in allowing judges to decide the application and scope of Bills of Rights, a society inevitably allows the substitution of judges' subjective moral views for the moral views of a democratically elected majority (for example, $\mathrm{p}$. 219). ${ }^{2}$ Waluchow writes:

Why should judges deciding moral questions under a system of judicial review be required, for reasons of democracy, fairness and the like, to respect the community's moral opinions on the matter - as opposed to the community's true moral commitments in reflective equilibrium? Why should they bend to the community's inauthentic wishes, not its authentic ones?... [J]udges are not philosopher-kings with a pipeline to moral truth. But they may be in a very good position to determine the requirements of a community's true moral commitments and authentic wishes in particular cases. If this is so... then there is nothing amiss in asking judges to enforce these commitments and wishes against the mere opinions and inauthentic wishes of the possibility misguided public gripped by evaluative dissonance. This is no more problematic than acknowledging the duty of responsible legislators... to do the same (pp. 225-6).

The debate over Charters and judicial review is in essence a debate over the nature of democracies. The question is a simple one: are majorities in democracies subject

1 Waluchow 2007.

2 All page references in brackets are to Waluchow 2007. 
to moral constraints? Proponents of Charters and judicial review typically claim they are, and that entrenching the constraints in a Bill of Rights with judicial review is the best institutional device for effective protection of the constraints. (Note, however, that there is no entailment relation here: one might take the position that there are moral constraints on majorities in democracies but that Charters and/or judicial review are not effective means to insure that these constraints are met.) Critics of Charters and judicial review however argue that there are no substantive constraints on what majorities can do in democracies. Majorities are constrained by processes and procedures only, not by substantive moral principles.

Waluchow takes a new and refreshing approach to this debate. He attempts to work out a position defending Charters and judicial review while at the same time avoiding the pitfalls of having to endorse a substantive conception of democracy. This is a considerable strength of his position. In particular, the distinction between inauthentic moral opinions and authentic moral commitments that is articulated in the book is a significant step forward. It allows him to adopt a purely procedural account of the constraints on majorities in democracies because for him majoritarian procedures are not democratic - i.e. are not self-governing procedures - when they are based on inauthentic moral opinions. The distinction also deflates prominent arguments of critics of Bills of Rights and judicial review (following Waluchow, 'Critics'), notably the argument from disagreement. If much, if not all, moral disagreement is disagreement between inauthentic opinions and authentic moral commitments, then it is not really disagreement at all. Discounting moral opinions does not interfere illegitimately with citizens' right to govern themselves in a democracy because moral opinions are inauthentic; they are not the preferences of agents acting autonomously. Moreover, the distinction enables Waluchow to adopt what I term a 'descriptive' methodology of constitutional interpre- 
tation. In making decisions on the basis of the authentic moral commitments of a community, interpreters (e.g. judges) are, by hypothesis, describing one set of expressed wishes of a community. Since, therefore, judges are in the business of empirical description, not of 'imposing' their subjective opinion on a substantive and contested issue, Waluchow's position should satisfy Critics.

My paper examines these aspects of Waluchow's argument. For Waluchow, paradigm cases of inauthenticity, at least the community case, are those in which people's reasoning capacities are distorted, for example, through fear, prejudice, emotional disturbance, drug or alcohol induced stupor, etc. As I explain, these failings are characterized as epistemic failings of agents or communities. I argue however than some of the failings that Waluchow describes as inauthentic are in fact substantive moral failing of agents. If so, then he implicitly builds into his position quite a strong, substantive, conception of autonomy. This substantive conception, while it is defensible, will not be acceptable to Critics. Neither will it allow Waluchow to maintain his purely procedural account of democratic self-government.

In the first section of the paper, I provide an exposition of the role played in Waluchow's argument of the moral opinions - moral commitments distinction. For Waluchow, the distinction is important in both legislative and adjudicative contexts. I explain the significance of the distinction, in particular its role in deflating the arguments of Critics. The second section is a critical examination of the possible methodologies of constitutional interpretation on Waluchow's 'living tree' or 'common law' account of Bills of Rights. I argue that there are three broad approaches possible, which I call subjective, descriptive, and constructive. I analyze Waluchow's methodology as descriptive; if it can be maintained, it would have considerable advantages in responding to the objection. I suggest however, that the methodology of interpretation in Bills of Rights cases is con- 
structive. ${ }^{3}$ In short, it involves substantive, 'evaluative and justificatory'4 reasoning by interpreters and judges. I claim that a constructive approach is better than a descriptive approach in explaining the common law model that is adopted by Waluchow. This does not mean, however, that it collapses into the subjective. In section three, I explore the moral opinions-moral commitments distinction in detail. I argue that the distinction either cannot to the work that Waluchow attributes to it, or if it is to be modified to do the work, it becomes a substantive distinction. A substantive conception of authenticity creates a problem for Waluchow in that it undermines his purely procedural account of democratic self-governance. In the final section, I briefly address the question: given that a constructive methodology, as a well as a substantive conception of democracy, seem necessary in many of the contested situations of constitutional morality of concern to Waluchow, what should we conclude about judicial review?

\section{Waluchow's Distinction Between}

\section{Moral Opinions AND MORAL COMMITMENTS}

(i) Authentic and inauthentic preferences. Waluchow introduces the idea of authenticity in Chapter 3. Consider a medical ethics case in which a patient, who is fully informed about her medical condition, and the options available to her, says that she wants to die. Waluchow imagines a response to the patient in the following terms:

[A] daughter is moved to declare "I know what she has just said, but that can't be my mother talking! She says she wants to die, but she has always believed in a duty to God to preserve one's life at all costs. To surrender to death in this way would be in her eyes to insult God - something

3 Ronald Dworkin famously introduced the notion of constructive interpretation in Law's Empire (1986), p. 52. Constructive interpretation is an example of a constructive methodology but not the only example.

4 See Dickson 2004, p. 119. 
she would never ever wish to do." In such a case, the patient might be described as speaking or acting out of character. One might go so far as to say that in such cases of "evaluative dissonance" it is "her condition" speaking, not her. If so, then one might be inclined to say that her consent cannot possibly be valid because it is inauthentic ( p. 87).

This kind of case sets up two potential conflicts: first, a conflict between the mother's expressed wishes and her best interests; and secondly, a potential conflict between her expressed wishes and her 'true' or authentic commitments. It is this second potential conflict that is the focus of our discussion here. Waluchow suggests that there are at least three necessary conditions of a wish being authentic: (i) it must be expressed sincerely; (ii) it must be 'based on adequate knowledge and understanding' (p. 89) and (iii) it must comply with the 'evaluative dissonance condition', that is, the condition that the 'wish expressed be consistent with the basic beliefs, commitments, values and settled preferences of the agent' (Ibid.). Failing the evaluative dissonance condition may be due to a failure of self-knowledge, and hence may fall under the second condition. The example of the mother above may be in this category. However, there are alternative ways of failing the evaluative dissonance condition. Waluchow claims that an agent "might be fully aware of the evaluative dissonance but might be temporarily overcome by profound fear or some other emotional disturbance' (p. 90). Suppose someone in a drunken state is 'fully aware of the risks of drunk driving and the extent to which such conduct violates [his] fundamental convictions and settled preferences' (p. 90) yet still demands to drive himself home. On Waluchow's account the expressed wish - a 'drink-enhanced, macho preference' - is inauthentic and hence the agent's friends are justified in removing his keys to prevent him from driving himself home.

(ii) Atticus and the language law. Once having introduced the distinction between inauthentic and authentic prefer- 
ences, Waluchow moves from the case of individual agents' wishes to those of a political community. What is the obligation of an elected representative in the face of the electorate's expressed wishes? Is it ever permissible to override the expressed wishes of the electorate when their expressed wishes conflict with (i) their best interests or (ii) their authentic interests? Waluchow sets aside the question of whether it is justified for a representative to paternalistically override an electorate's expressed wishes in the name of their best interests. Rather, he argues for the weaker position that it is sometimes a legitimate requirement for a representative to override 'one set of expressed wishes - the inauthentic ones - for the sake of honoring other expressed wishes, the genuine ones.' (p. 97).

Consider the example of an imaginary democracy, Demos, which contains (among others) a constituency, Athenia, whose elected representative is Atticus. Athenia and Demos contain a small minority, the Venusians, who have a distinct linguistic, religious, moral and cultural identity. Suppose that the parliament in Demos - supported by the majority in Athenia - wishes to enact a language law denying Venusians 'the right to use the Venusian language...despite the fact that Venusians are fluent in no other language' (p. 98). Waluchow canvasses various possible reasons of the majority might have for supporting the law. First, the law may be justified in the eyes of the majority because it will produce the greatest good for the greatest number': it will be convenient, economically efficient, and so forth (p. 99). On this justification, the majority either does not appreciate the full extent of the harm to the interests of the Venusians or is indifferent to the interests of the Venusians in prohibiting the Venusian language. Secondly, the majority may be motivated by 'simple prejudice': the majority in Athenia 'might be deeply prejudiced against Venusians and be prepared to deny them full rights to free expression; even when the costs are 'quite minimal' (p. 100). Thirdly, the majority might be fearful of Venusians 
as 'the Other.' Here Waluchow uses the parallel of the internment of Japanese during WWII. 'Fear of the unknown... [led to] deep suspicion and oppressive measures' against Japanese and those of Japanese descent (p. 100). How should Atticus - who after all must consider himself to be the representative of the majority in Athenia - respond to these reasons for voting for the proposed law?

Waluchow argues that Atticus should treat the majority's wish to enact the language law as inauthentic. The language law fails the evaluative dissonance condition for this political community: 'we have dislike, prejudice and hatred fuelled by fear, together with a demand for action that introduces significant evaluative dissonance. Demos, we may suppose, is a community that values moral equality. In other words, among its basic commitments is the belief that all persons are entitled, as full members of the moral community, to what Ronald Dworkin calls "equal concern and respect"' (p. 104). Demos' true and authentic commitment to equality is incompatible with denying a minority the right to free expression - at least when that denial, as it is by hypothesis in this case, is based on fear, prejudice, indifference or lack of appreciation of the harm to the minority's interests.

(iii) Inauthentic inputs defeat democratic self-governance. Waluchow's argument, however, does not end here. Although Atticus believes that the law is morally wrong, he is still reticent about voting against it for the following reasons: 'Demos is a democracy, and whatever else we might mean in calling a system democratic, we mean that it is a system where "the people" are the ones who ultimately rule... [R]ight or wrong, Athenians have by way of a clear majority consensus, determined that their wish is to see a language law enacted' (p. 105). One way of rebutting this objection would be to adopt a substantive or 'constitutional' conception of democracy. This kind of conception is out- 
come-related. ${ }^{5}$ In other words, majoritarian procedures are truly democratic only to the extent that they produce outcomes that satisfy independent necessary conditions of democracy, for example 'the principle of equal status' (p. 108). This conception of democracy has been the target of Critics of Charters and judicial review. ${ }^{6}$ The alternative conception of democracy - one that is acceptable to Critics - is that it is purely procedural or process-related. ${ }^{7}$ The device of evaluative dissonance allows Waluchow to argue that even on the latter conception of democracy, Atticus may legitimately discount majoritarian preferences when they are inauthentic. He claims that: majoritarian procedures are not democratic - i.e. are not self-governing procedures - when they are based on inauthentic wishes (pp. 111-12, my formulation). They are not self-governing in the same way that decisions made agents who are drunk are not self-governing, or the decisions of the mother that she wishes to die are not self-governing. A necessary condition of self-government is authenticity, and, in all three cases, the expressed wishes fail this condition. I return to this argument in section 3 of the paper.

(iv) Constitutional morality and the arguments of Critics. In Chapter 6 of the book, Waluchow outlines the heart of the argument for judicial review. One aspect of this argument employs a distinction between a community's moral opinions and its moral commitments. Waluchow points out that there is in fact a three way distinction within the morality of a community: first, a community's inauthentic moral wishes or opinions; secondly, a community's 'true' morality 'broadly construed;' and thirdly, a community's constitutional morality. The latter is 'the set of moral norms and considered judgments properly attributable to a community as a whole as representing its true commitments, but with the following additional property: They are in some way tied

5 Waldron 2006, p. 1376 ff. See Waluchow's discussion on pp. 106-109.

6 Especially of Jeremy Waldron. Waldron 1999a, 1999b and 2006.

7 Waldron 2006, p. $1386 \mathrm{ff}$. 
to its constitutional law and practices' (p. 227). One way of understanding a community's constitutional morality would be to adopt Ronald Dworkin's notion of the set of principles of political morality implicit in a particular area of law. Waluchow is careful to distinguish, however, the Dworkinian notion of a political morality that is best justified from a moral point of view from the political morality that explains the community's actual laws and institutions. He adopts the latter as his account of constitutional morality: for example, 'much of early twentieth century South African law [presupposed] racist moral norms and beliefs. Such norms and beliefs were part of that community's (deplorable) "constitutional morality" (Ibid).

How do we distinguish between moral opinions and true moral commitments that constitute a community's constitutional morality? Waluchow employs two theoretical devices, both drawn in broad terms from the work of Rawls. First, he argues that even if there is significant disagreement within a community over moral opinions, there is a degree of overlapping consensus over true moral commitments. Second, as in the personal case, only those moral opinions that are in reflective equilibrium - that are consistent with moral principles held by the community - will be considered to be true moral commitments. Consider the mother above: her wish to die is not authentic because it is inconsistent with her deeply held moral principles, or to put it another way, with what she would be committed to under conditions of maximal rationality, evidence, etc. Similarly, a community's moral opinions, such as those that suspected terrorists should be locked up indefinitely without charge, are inconsistent with the community's deep moral principles. Waluchow acknowledges that in some cases disagreement remains about what the moral commitments themselves. He writes: 'on some highly contestable questions, for example questions concerning the morality of abortion, there may be no overlapping consensus...If so then the community's constitutional morality will fail to 
provide determinate answers in Charter cases...But there is little reason to think that this will always be so.' (pp. 228-9). For Waluchow, then, cases of genuine, substantive disagreement are in the minority.

Waluchow's notion of constitutional morality therefore addresses two important arguments of Critics of judicial review. The first is the argument from disagreement, in particular the claim that because substantive disagreements about moral rights go "all the way down,' 8 the only democratically legitimate way to resolve the issue is by appealing to parliament, that is, to the elected representatives of the people. The notion of overlapping consensus however rejects the position that disagreement goes all the way down. There is some set of moral principles which we agree on and which in principle can be identified by judges (or others). The notion of authentic moral convictions in reflective equilibrium also addresses the argument from disagreement. It shows that some disagreement -indeed perhaps much disagreement - can be discounted because it is disagreement over moral opinions or between moral opinions and moral commitments. Disagreement when it is based on mere opinion can be discounted because it is only apparent disagreement; it is not genuine disagreement over substantive issues. A second argument of Critics, the argument from autonomy, relies directly on a premise about citizens' autonomy. Jeremy Waldron claims that there is an internal contradiction within the case for Bills of Rights and judicial review. ${ }^{9}$ On the one hand, the attribution of rights to citizens presupposes that they are autonomous, rational agents deserving of rights; on the other, the institution of judicial review undermines the autonomous agency of citizens to resolve moral controversies about rights for themselves, because it allocates this power to a small group of

8 Waldron 1999a, p. 295. Waluchow outlines the argument from disagreement on pp. 156-7.

9 Waldron 1999a, p. 222. This argument is discussed in Waluchow 2007, p. $150 \mathrm{ff}$. 
elite judges. Thus Charters together with judicial review both attribute and deny autonomy to agents. The moral opinions - moral commitments distinction could be used to respond to this argument. If expressing a 'mere opinion' is not a manifestation of an agent's autonomy, then there is no obligation on anyone, either a judge or a legislator, to respect the opinion. Resolving a putative 'dispute about rights' by discounting a mere opinion does not undermine a citizen's democratic right to have her voice count or to autonomously resolve the dispute herself.

\section{Methodology AND Constitutional InTERPRETATION}

A crucial ingredient in Waluchow's defense of Charters and judicial review is his 'common law' or 'living tree' conception of Charters. In this section I examine the methodologies of interpretation that are available on a common law model. I argue that Waluchow's methodology is (most likely) descriptive, whereas the best account of interpretation on the common law model is constructive.

(i) The 'living tree' model. For Waluchow, Charters do not constitute a 'pre-commitment' or agreement about citizens' rights that is fixed at the time of framing or adoption. Rather, the rights enumerated in a Charter evolve to reflect the changing nature of the democracy over time: '[i]t is an instrument that must be allowed to grow and adapt to new contemporary circumstances and evolving normative beliefs, including those about justice' (p. 183). Waluchow's position raises the question of the relationship between the written Charter and evolving constitutional morality. He notes that his common law conception 'seeks to combine the relative fixity of entrenched written law, and the adaptability characteristic of the common law' (Ibid.). ${ }^{10}$

I will not be concerned here to either endorse or critique this conception of common law reasoning, or the plausibil- 
ity of applying the model to Charters and statute law. Rather, I want to explore the methodology of constitutional interpretation, broadly construed, that is presupposed by the common law conception of Charters. As Waluchow points out, the living tree conception of Charters rules out theories of constitutional interpretation that adopt a 'fixed point' analysis of Constitutions and bills of rights. This includes all versions of originalism, ${ }^{11}$ even the moderate versions, such as the 'utterance meaning' intentionalism of Jeffrey Goldsworthy. ${ }^{12}$ It also rules out, for example, apparently intermediate approaches such as the one adopted in early articles by Ronald Dworkin. ${ }^{13}$ On these intermediate accounts, it is granted that constitutional language, especially the language of Bills of Rights, is broad and abstract. However it is argued that the broad, abstract language corresponds to an 'abstract intention' of the founders of Constitutions. The framers of the Equal Protection amendment of the United States Constitution, for example, had an intention to enshrine an abstract principle of equality. For these authors, the abstract intention is the intention to entrench whatever set of requirements 'equality' denotes in our best moral theory of equality. This may look like an evolutionary conception, but it is not. 'Equality' denoted the same set of moral requirements 200 years ago as it does today, even if the then legal experts did not realize it.

However, there are three broad methodologies of constitutional interpretation that are compatible with the common law model of Charters: subjective, descriptive and constructive. The first, subjective methodology, claims that the only way of resolving contested issues of the interpretation of rights is by resorting to an interpreter's subjective moral position. Samuel Freeman usefully distinguishes between different practical points of view. The subjective methodol-

11 Prominent proponents of originalism include Bork 1990, and Scalia 1997.

12 For example, Goldsworthy 1997.

13 Dworkin, 'Forum of Principle' in Dworkin 1985. Brink 1988 also argues for abstract intention as the basis of interpretation. 
ogy, in Freeman's terms, employs 'particular' reasons, the reasons that are 'ascertained from our individual perspectives, where we see ourselves as single agents with fixed (final) ends facing a range of options from which we must choose. These reasons are ultimately based on our particular ends, as given by our private, sectarian, and group interests.' 14 Critics of Charters and judicial review typically think that once abstract moral principles are entrenched in Bills of Rights, and the power to decide contested cases is allocated to judges, subjective interpretation of this sort is inevitable. However I argue that the descriptive and constructive methodologies of interpretation provide genuine alternatives to the subjective model. The distinction between descriptive and constructive methodologies of interpretation corresponds to a distinction that is drawn within the methodology of law more broadly. A descriptive methodology of law is attributed to exclusive and inclusive positivists whereas a 'evaluative and justificatory' methodology of law is attributed to Ronald Dworkin. 15

The descriptive methodology claims that interpreters must attempt to describe a community's actually held values and principles, to describe, for example, its constitutional morality. Once interpreters latch on to the 'true' moral commitments of a community, many of the contested questions disappear. A descriptive methodology, of which originalism is one important example, has an enormous advantage over alternatives because interprets can claim the neutrality that has been sought by so many theorists of interpretation. ${ }^{16}$

I suggest that Waluchow's methodology of interpretation is an example of descriptive methodology. Four aspects of his discussion come together to constitute the descriptive approach. First, he argues that there is an existing (and therefore describable) 'overlapping consensus' within demo-

14 Freeman 1992, p. 22

15 Dickson 2004.

16 See the discussion in Freeman 1992, p. $21 \mathrm{ff}$. 
cratic communities; that is, there is agreement on the broad moral principles to which the community is committed. Secondly, he claims that, in cases of controversy, it is legitimate to override 'one set of expressed wishes - the inauthentic ones - for the sake of honoring other expressed wishes, the genuine ones' (p. 97). In other words, the genuine wishes can be identified and described by legislators and judges. Thirdly, Waluchow distances his position from that of Dworkin. As noted above, he describes Dworkin's notion of political morality as the one that is best justified from a moral point of view, whereas his own explains the community's actual laws and institutions. Fourthly, he implicitly offers independent, apparently non-normative criteria for identifying inauthentic preferences and opinions. Moral preferences that are fuelled by fear, hatred and prejudice are examples of preferences that can be discounted as inauthentic. These are descriptive, empirical features of agents. So, four elements of Waluchow's current theory point to a descriptive methodology of constitutional interpretation. In addition, a descriptive methodology is supported by Waluchow's theory of law broadly understood, that is, by his commitment to inclusive positivism. ${ }^{17}$

I now turn to the constructive methodology. On constructive models of constitutional interpretation, interpreters are adopting a normative and justificatory methodology, one in which a substantive answer to a question of moral principle is being articulated and defended. They theorize about what the community would or should believe, often employing some set of idealized conditions, and attempt to refine what we, a community, mean by a concept in a way that improves' the concept relative to factors such as the goals of the practice in question. (Hence this approach may also be termed 'ameliorative.'18) One example of a constructive methodology is Freeman's notion of 'public' reason, a prac-

17 See Waluchow 1994.

18 I explain the idea of an ameliorative methodology in another paper. See (draft). 
tical point of view that he contrasts with the particular or subjective point of view described above. Freeman says: '[I]f reasons are to serve a justificatory role in a democracy, they must ultimately be acceptable to everyone from a public point of view...[This] is a position where free persons abstract from their individual perspective and the reasons and interests that set them apart and reflect upon measures that realize their interests as democratic citizens.' 19

Notice that although Critics assume that the constructive project will collapse into a subjective one, this is not the case. The subjective approach entails that interpreters always interpret for their own, particular, reasons and purposes. As Waluchow usefully points out several times in his book, judges are constrained by a 'good faith requirement:' '[an interpreter] may be free, in the de facto sense, to choose an interpretation that she thinks wrong but that serves her purposes. But she is not free in the relevant normative sense. She is constitutionally required to interpret...honestly in the best way she can and to act on that interpretation' (pp. 39-40). For example, if neutrality in interpretation corresponds to some conception of public rather than particular reason, good faith requires judges to interpret on the basis of their best understanding of public reason - i.e. on the basis of principles applicable to all citizens - and not on the basis of their particular and subjective purposes. Moreover, it is worth reiterating Waluchow's important distinction between a decision that relies on the personal view of judges or interpreters, and a decision that attempts to promote a judge's subjective purposes and goals (see e.g. p. 231). Proponents of the subjective methodology often conflate these two kinds of decision. As Waluchow points out, scientific decisions rely on the "personal judgments of scientists about what the evidence establishes' (p. 231) but it does not follow that scientific conclusions are expressions of subjective reasons and goals of individual scientists. 
The common law model defended by Waluchow is better described as employing a constructive, not a descriptive, methodology. To see this, consider the analysis of Denise Reaume that is adopted by Waluchow to argue that reasoning about Charter rights should be 'bottom up' rather than 'top down' (p. 204 ff.) Reaume suggests that the (statutory) law of discrimination should follow a 'bottom up' rather than a 'top down' model. She argues that because we want discrimination law to be informed by moral concepts such as justice and liberty, it is therefore 'wise not to attempt a comprehensive theory issuing in a precise network of rules at the outset, but rather to let the implications of the abstract principles be revealed incrementally through confronting fact situations on a case-by-case basis.' 20 Waluchow proposes that, in the same way, the constitutional law of rights evolves in small steps in which broad, general principles are made precise in the context of hitherto unforeseen particular cases. (One example is the way in which the Canadian Charter's s.15 right to equal protection has been refined through its application to the (unforeseen) issue of same-sex marriage. In the Halpern case, the Ontario Court of Appeal held that the traditional legal understanding of marriage as a union between a man and a woman is a violation of the equal protection right of same-sex couples. ${ }^{21}$ ) Although at the beginning of the book, Waluchow comments that '[a] Charter is best viewed as a device for dealing with our epistemic limitations,' (p. 11) the process of common law reasoning is more than an epistemic process of finding out what the law is: it is a process of 'lawmaking.' As Schauer (quoted by Waluchow) puts it: 'common law rules are created by courts simultaneously with the application of those rules to concrete cases.' 22

Waluchow may respond that there is an overlapping consensus over abstract principles, such as the principle of

20 Reaume 2002, p. 117. Quoted by Waluchow on p. 207.

21 Halpern v. Canada (Attorney General), [2003] O.J. No. 2268.

22 Schauer 1989, p. 455 quoted by Waluchow, p. 197. 
equality, and the question in an unforeseen case, such as that of same-sex marriage, is to work out what the moral commitment to equality entails. It is to work out - describe' - what the constitutional morality of equality actually says about same-sex marriage, not to create law in an area in which hitherto there was none. This response would fly in the face of elements of Waluchow's own argument for the common law conception, however. In developing the common law understanding of Charters, Waluchow relies on well-known insights of H.L.A Hart about rules and their application in unforeseen cases. ${ }^{23}$ Hart pointed out that rules, including common law rules, contain general terms, and that general terms are 'open textured;' they have the potential to encounter vague applications in actual cases. General terms like 'vehicle' are vague because there are cases - like that of 'aeroplane' - which are neither clearly vehicles nor clearly not vehicles. This is a kind of linguistic vagueness, and for Hart, the indeterminacy resulting from vagueness leads to genuine legal indeterminacy. ${ }^{24}$ If Hart is right, and in these cases there is a genuine indeterminacy or gap in the law, then there is no law on the relevant matter. The term will have to be 'precisified' - the vagueness will have to be resolved - when the concrete case comes before a court. Moreover, for Hart, the linguistic vagueness is a good thing, because, as Waluchow emphasizes, '[w]e can sometimes foresee that situations are very likely to arise in which blind pre-commitment to a particular legal result would have been foolish or morally problematic' (p. 196). Thus, there are normative reasons as well as conceptual reasons arising from linguistic vagueness for the conclusion that common law methodology is constructive, not descriptive.

A further aspect of unforeseen cases noticed by Hart is that the interpretation of borderline cases 'brings with it a

23 See Waluchow's discussion of the 'circumstances of rule making', pp. 194-199 and pp. 258-270.

24 Hart 1961, Chapter VII. 
relative indeterminacy of aim,' 25 which requires a weighing up of different and competing considerations. In the case of a rule 'No vehicles in the park' applied to whether a child's toy car should be permitted in the park, it will have to be decided 'whether some degree of peace in the park is to be sacrificed to, or defended against, those children whose pleasure or interest it is to use these things. ${ }^{26}$ Similarly, in the constitutional context, unforeseen cases may raise questions not only about whether a general moral commitment is applicable to a particular fact situation but also about the strength, or weight, of our moral commitments when competing interests arise. A recent example is the Canadian case of Charkaoui. ${ }^{27}$ It concerned legislation whose aim was to promote national security, which in effect allowed the indefinite detention of non-citizens who were suspected of terrorist activity. A unanimous (9-0) decision of the Supreme Court of Canada held that the legislation was inconsistent with the constitutional right to life, liberty and security of person. For a proponent of a descriptive methodology, the 9-0 decision could be used as evidence that the Court identified and described a 'true' principle of constitutional morality, which, simply put, is that constitutional rights must be given greater weight than considerations of national security. This descriptive analysis however implies that the legislature's position is inauthentic, 'mere,' opinion. Is this a plausible position? Alternatively, is there a substantive issue at stake of how national security should be weighed against rights? I suggest that the case is better characterized as exemplifying a constructive approach; it makes precise a substantive aspect of constitutional morality, namely the scope and weight of the constitutional right to life, liberty and security of person in national security contexts.

25 Hart 1961, p. 125.

26 Ibid.

27 Charkaoui $v$. Canada (Citizenship and Immigration), 2007 SCC 9 (The Security Certificates Case). 
I have argued that the common law model of constitutional interpretation that is adopted by Waluchow is best described as invoking a constructive methodology. This model provides a genuine alternative to both the subjective model adopted by Critics and the descriptive model adopted (implicitly) by Waluchow himself. On the constructive model, reasoning about constitutional morality in contested cases is substantive normative and justificatory reasoning in which interpreters refine and make precise our constitutional commitments by applying them to concrete cases when they arise. There is a tension, then, in Waluchow's argument. His notion of constitutional morality and the accompanying examples presuppose the descriptive model; whereas the common law model of reasoning that he also endorses presupposes the constructive model.

\section{InAuthentic Versus Authentic Moral Commitments}

Waluchow claims that inauthentic moral opinions of individuals cannot form part of a self-governing or democratic constitutional morality, and thus can be discounted by legislators as well as judges engaging in judicial review. It is essential therefore, to understand precisely the necessary conditions of inauthenticity or nonautonomy in the individual case. The distinction is contested in the relevant literature. On some views, autonomy is ubiquitous and what look like mere opinions may be considered to be autonomous; on others, true autonomy is quite rare: an agent is truly autonomous only if her commitments correspond to the moral commitments delivered by our best moral theories. Many theorists however consider that a criterion of a correct theory of autonomy is that it distinguish between self-rule and right-rule. ${ }^{28}$ There must be room on a theory of autonomy (or authenticity) for agents to adopt moral po- 
sitions that are, from some better moral perspective, wrong positions. Otherwise, conceptually speaking, self-rule would collapse into right-rule. This holds for communities as well as individual agents. Waluchow's acknowledges this when he says that: '[J]udges are not philosopher-kings with a pipeline to moral truth;' that is, he distinguishes the authentic moral commitments of a community from commitments that are morally correct.

Let us look once again at the paradigm cases of individual failure of autonomy that Waluchow identifies, those of the ill woman and the drunken driver. Waluchow relies on a 'reflective equilibrium' analysis of these cases: moral opinions are defined as 'moral views that have not been critically examined so as to achieve reflective equilibrium' and moral commitments are 'those that have' (pp. 223-224). However, the device of reflective equilibrium, on its own, will not achieve the desired result, for bringing the opinions and the commitments into equilibrium, namely removing inconsistencies and evaluative dissonance, will not on its own tell us whether it is the opinions that need to be jettisoned or the commitments that need to be modified to absorb the opinions. As Waluchow points out, there must be room on these analyses for change in commitments at both the level of agents and the level of community. Waluchow's examples of inauthentic moral views suggest that there are independent epistemic conditions that true moral commitments must meet. Moral commitments - as opposed to mere opinions - are those satisfying a test of 'critical examination;' for example, they cannot be the result of prejudice, fear, inadequate evidence, or emotional turmoil. If the moral view is epistemically flawed in any of these ways, it is inauthentic; it does not constitute a true moral commitment and can be disregarded. The commitment that one should not drink and drive satisfies the test. It is formulated by a rational, informed, clear-headed agent. On the other hand, the desire to drive while drunk is formulated by an agent whose mind is clouded by alcohol. Thus, bringing 
the two desires into equilibrium entails rejecting the latter. The ill woman example is perhaps less clear because it may be a rational response to severe pain of illness to modify one's commitment to the sanctity of life. However, it can be supposed that the ill woman is temporarily in the grip of fear or emotional disturbance and therefore that the wish to die fails the test of critical examination and does not express her true character.

In this section, I develop the following response to Waluchow's position. The 'critical examination' test of authenticity can be understood in either of two ways. The first is as a test that requires agents' reasoning to satisfy purely epistemic or non-moral conditions; the second is as a test that requires agents' reasoning to satisfy some moral condition or conditions in addition to the epistemic, non-moral conditions. If it is understood as a purely epistemic or non-moral test, then reasoning based on prejudice and hatred will not count as inauthentic. However, if it is understood as in part a moral test, then this will undermine Waluchow's purely procedural conception of democratic self-governance. I look at each option in turn.

Suppose first that Waluchow's test is a purely epistemic or non-moral test. If so, it would fall into a category of theories of autonomy I will call procedural, namely those claiming that it is necessary and sufficient for autonomy that an agent's processes of preference-formation comply with certain non-moral, or procedural, conditions. ${ }^{29} \mathrm{~A}$ prominent example of a procedural theory is the position that the feature necessary for autonomous reasoning is an agent's identification or endorsement. On Harry Frankfurt's famous theory, this is spelt out using different levels of the self. ${ }^{30}$ Autonomy or authenticity, with respect to a lower-level fea-

29 For a discussion of the distinction between procedural and substantive theories, see Mackenzie and Stoljar 2000b. See Benson 2005 for an analysis and critique of substantive views.

30 Frankfurt 1971. Frankfurt has modified his postion several times since this paper but these modifications need not concern us here. Gerald Dworkin articulated a similar position in Dworkin 1970, 1988. See Taylor 2005 for an overview. 
ture of the self (that is, a desire, opinion, or preference), is the endorsement of the lower-level feature by one at a higher-level. In the absence of such endorsement, the agent is, as Frankfurt puts it, a 'passive bystander' with respect to the lower-level feature of the self. So, for example, on this theory the ill woman's desire to die is autonomous if and only if it is endorsed at a higher level; that is, if and only if she also has a desire to desire to die. Since by hypothesis she does not have this higher-order desire, her desire to die is not autonomous. Similarly, the drunken driver does not endorse his lower-level desire to drive when drunk, and hence the latter is also not autonomous. A second kind of example is Sarah Buss's claim that autonomy is undermined when an agent's reasoning processes are unhealthy or distorted. She writes that the key to... self-governing agency is the distinction between a healthy human being and a human being who suffers from some psychological or physiological "affliction" (e.g., intense pain, fear, anxiety, fatigue, depression, and obsession).' 31 On this approach, the conditions required for autonomy are - deliberately - not particularly stringent. An agent who suffers an affliction that is severe enough to distort and pathologize her capacity for reasoning is nonautonomous; otherwise her reasoning is autonomous. (On this position, the drunken driver would be ruled as nonautonomous, but the ill woman may or may not suffer from a sufficiently severe affliction - it would depend on the details of the case.) A important feature of both accounts of autonomy is that they are "content-neutral.' 32 Preferences or opinions are not ruled autonomous or nonautonomous on the basis of their contents; rather, it is an agent's healthy or unhealthy condition, or the attitude that she adopts to her preferences, that provide

31 Buss 2005, p. 215. See also Raz 1986, p. 374 in which he describes a woman on a desert island who is hounded by a wild animal. Raz's 'hounded woman' suffers an affliction of this kind.

32 For discussions of the notion of content-neutrality, see Christman 1990 and Benson 1994. 
the keys to whether her reasoning is autonomous in a particular case.

It is not obvious, however, that Waluchow's example at the community level - that of the preference to deny the Venusian minority the right to use their own language - would count as nonautonomous on either of these accounts of autonomy, or on procedural accounts in general. Recall Waluchow's argument that the language law fails the critical examination condition because: 'we have dislike, prejudice and hatred fuelled by fear, together with a demand for action that introduces significant evaluative dissonance...(p. 104). Neither the 'afflicted agent' account, nor the endorsement account, would treat prejudiced opinions as inauthentic. Prejudice - in brief, the unjustified or arbitrary belief that an individual or a group is less morally worthy - may be a moral failing, but it is not a physical or psychological affliction; nor, unfortunately, is it impossible for agents to authentically adopt and endorse such flawed moral beliefs. Inputs into the democratic consensus that are the result of prejudice and hatred are not inauthentic on these common theories of autonomy.

Certain conditions on Waluchow's list - those of emotional turmoil and ignorance, for example - can readily be included among the procedural conditions of autonomy. However, others, like that of prejudice, are 'overinclusive.' Consider, for instance, White supremacist minorities in the United States, Canada or elsewhere, whose beliefs are incompatible with the constitutional morality of those countries. The beliefs of White supremacists are based on prejudice and hatred. But are such beliefs, for that reason, inauthentic and failures of self-government? It would seem not. First, our intuitions about the 'true' character of White supremacists suggest that it is precisely the prejudiced, racist beliefs that make them what they are. Secondly, characterizing White supremacist beliefs as inauthentic, that is, as not an expression of the individual's free agency, creates a prima facie problem for the attribution of moral 
responsibility to agents who hold these beliefs. ${ }^{33}$ Yet, it seems that White supremacists are morally responsible for their beliefs and for any actions taken as a result of those beliefs. Thirdly, suppose White supremacists set up a society in which their beliefs are permissible under the society's morality. Because the society's morality is based on prejudice and hatred, it does not satisfy the critical examination test, and so it does not exhibit democratic self-governance or authentic constitutional morality. However, Waluchow claims that societies like this one -Nazi Germany and apartheid South Africa- would have a constitutional morality, albeit a morally repugnant one. These observations suggest, then, that prejudice, or rather lack of prejudice, should not be included as one of the epistemic conditions in Waluchow's critical examination test.

If lack of prejudice is not included as a necessary condition in the test of authenticity, Waluchow's example seems less convincing. Consider again the preference of the majority in Demos to deny the minority Venusians the right to use their own language. Suppose this preference is the result of prejudice against Venusians as well as lack of information both about the importance of language to the minority, and about the implications for freedom of expression of denying language rights. Because of the epistemic flaws in the majority's reasoning, the preference fails the critical examination test and hence is inauthentic on Waluchow's account. Now imagine a variation on the case. Suppose that the supporters of language rights mount a public campaign - much like an election campaign - on behalf of the Venusians. As a result, newspapers, radio and television are saturated with advertisements in support of language rights; they broadcast documentaries and news items about the unique language and culture of the Venusians; and they re-

33 A version of the problem is faced by theorists who adopt moralized conceptions of autonomy: see discussion in Benson 1994, p. 660. The problem is that, on these conceptions, acting freely seems to amount to the same thing as acting morally responsibly, and therefore inauthenticity implies lack of moral responsibility. 
port on and discuss the politics of the campaign. Suppose the campaign is pursued over a period of weeks or months so that it is reasonable to think that the majority is as well-informed as non-specialists in a society can be about their political choices. Nevertheless, although some members of the majority change their minds, the remainder is unpersuaded. For them, the information available does not have the desired effect of overriding their prejudices; the minority's rights are not sufficiently important to outweigh their own concerns. In other words, preferences to deny rights to minorities - even those based in prejudice - cannot always be treated as inauthentic. Once these preferences satisfy a (non-moral) test, they constitute genuine moral commitments, and hence the problem of substantive disagreement over rights reappears.

If however lack of prejudice is retained as one of the necessary conditions of critical examination, this brings us to the second possibility mentioned above, that the test of authenticity adopted by Waluchow is really a moral one. Prejudice is blindness of a sort, but it is not simply epistemic blindness, which would be cured given better epistemic conditions. Prejudice is blindness to others' moral worth. The claim that opinions based on prejudice are inauthentic implicitly introduces a moral criterion into the theory of autonomy. Opinions with certain moral contents - namely that members of minorities have lesser or insignificant moral worth - are judged to be inauthentic. Although such a substantive position is in principle defensible, it commits Waluchow, I think, to a corresponding substantive notion of democracy. It also brings Waluchow's position close to that of Ronald Dworkin.

Dworkin also argues that inputs into a democratic moral consensus must satisfy certain epistemic conditions to be legitimate. Although he does not rely on the notion of inauthentic opinions, the structure of his argument parallels that of Waluchow. In the context of a famous debate with Lord Devlin over the criminalization of homosexuality, 
Dworkin asks: What is it to speak of a group's morality or moral beliefs? What are the necessary conditions of a legitimate moral consensus? For Dworkin, some reasons (inputs) are disqualified from the democratic moral consensus, and, the necessary conditions of disqualified reasons are primarily epistemic. For example, reasons are disqualified if they are prejudiced beliefs, that is, beliefs that 'a member of a class automatically deserves less respect, without regard to anything he himself has done'; ${ }^{4}$ personal emotional reactions, such as disgust; beliefs based on false facts; or parroted beliefs adopted from others, such as 'everyone knows homosexuality is a $\sin .{ }^{\prime} 35$ On this test, neither the moral consensus of Nazi Germany nor that of apartheid South Africa would be democratically legitimate because, in both these societies, it was believed that certain classes of people deserved less respect. There is, then, a moral claim built into Dworkin's test of a legitimate democratic consensus; and in the same way, Waluchow's test of critical examination, when it is understood as including a lack of prejudice condition, is not purely epistemic but moral as well.

The main conclusion to be drawn here is that, if Waluchow's test of authenticity is to do the work it is required to do - namely, classify preferences denying rights to minorities as inauthentic - it must be construed as a moral test. The distinction between inauthentic moral opinions and authentic moral commitments is a moral distinction. What follows for Waluchow's argument about democracy? In one respect his argument remains in tact: he can continue to claim that inauthentic preferences are not genuinely self-governing and therefore majoritarian process that employ inauthentic preferences are not democratically legitimate. However, because authenticity itself is a moral concept, this position will presuppose a substantive conception of democracy not a purely procedural one. Majoritarian procedures will be judged inauthentic and hence not demo-

34 Dworkin 1977, p. 250.

35 Ibid. 
cratic if they violate some moral condition, for example if they exhibit that morally criticizable attitude of prejudice. So the ultimate test of democracy, on this alternative, is a substantive moral one as well.

\section{Conclusion. Back to The Question of Judicial Review}

Charters and Bills of Rights enumerate abstract moral principles. On the living tree model, our understanding of the abstract principles will evolve and be refined as over time they are applied to unforeseen cases. I have argued that this process is constructive, evaluative and justificatory. Each step in the evolution of principles requires a substantive decision about the scope or weight of rights. This does not entail, however, that it is a subjective process in which the reasoner decides the question according to her own particular ends or interests. I also suggested that the preferences of concern to Waluchow - namely, preferences that seem to deny constitutional rights to minorities - cannot plausibly be analyzed as inauthentic unless we adopt a moral notion of authenticity. It follows that, even if we classify some disagreements over rights as disagreements between inauthentic opinions and authentic commitments, these disagreements are nevertheless moral disagreements. In cases in which courts take a side in the disagreement that is not endorsed by the majority through the legislature, this implicitly imposes a moral constraint on majoritarian procedures.

How do these conclusions affect the question of the legitimacy of judicial review? The answer depends in part on the answer to the simple question posed at the beginning: are majorities in democracies subject to moral constraints derived from fundamental rights? For those who say 'yes,' the question of the justification of judicial review is to a large extent an empirical - or instrumental - one. For instance Joseph Raz says that we should adopt 'whichever political procedure is most likely, in the circumstances of the time 
and place, to enforce [rights] well, with the fewest adverse side-effects.' 36 The judiciary should not be idealized, but neither should the legislature. As Waluchow points out at the end of the book, we need to look at the "contexts of decision' for different procedures: the judicial and legislative contexts are different in crucial ways (pp. $255 \mathrm{ff}$.).

Even for those who say 'no,' it does not follow that judicial review is a flawed procedure. It is possible for the procedure of judicial review to itself be adopted by majoritarian processes; 37 the democratic legitimacy of judicial review would not, therefore arise ex nihilo, but rather through delegation of power to the judiciary by the majority. Waluchow mentions one compelling reason for this: the 'bottom up' methodology of constructive interpretation in which matters are decided incrementally cannot "easily or sensibly be dealt with...by an already overworked legislature. The latter would likely be swamped were it to assume, in addition to its already onerous duties, the additional responsibility to decide all unforeseen hard cases...' (p. 262). Thus, although work will have to be done to establish that judicial review is a better decision procedure, this is not - as Critics have sometimes claimed - an impossible task.

\section{REFERENCES}

Benson, P. 2005, "Feminist Intuitions and the Normative Substance of Autonomy", in Taylor, J. S. (ed.) Personal Autonomy: New Essays on Personal Autonomy and its Role in Contemporary Moral Philosophy Cambridge, Cambridge University Press

36 Raz 1998, p. 45. See Waldron's discussion of Raz's position and those of others relying on 'outcome-related' reasons in Waldron 2006, pp.

37 Christiano 2000, p. 521. Christiano imagines a situation such as a consitutional convention in which there is higher-order agreement to institute a lower-order non-majoritarian procedure: 'It is a contingent fact, dependingon the views and interests of those who choose the lowest order procedures, whether they choose a majoritarian procedure or not' (Christiano 2000, p. 521). 
1994, "Free Agency and Self-Worth", Journal of Philosophy 91, 650-668.

BRINK, D. O. 1988, "Legal Theory, Legal Interpretation and Judicial Review”, Philosophy and Public Affairs 17, 105.

BoRk, R. 1990, The Tempting Of America, New York, Touchstone.

Buss, S. 2005, "Valuing Autonomy and Respecting Persons: Manipulation, Seduction, and the Basis of Moral Constraints", Ethics 115, 195-135.

Christiano, T. 2000, "Waldron on Law and Disagreement", Law and Philosophy, 513-5143.

Christman, J. 1990, "Autonomy and Personal History", Canadian Journal of Philosophy 20, 1-24.

DICKSON, J. 2004, "Methodology in Jurisprudence: A Critical Survey", Legal Theory 10, 117.

Dworkin, G. 1970, “Acting Freely”, Nous 3, 367-83.

1988, The Theory and Practice of Autonomy, New York, Cambridge University Press.

DwORKIN, R. 1977, "Liberty and Moralism", in Taking Rights Seriously. Cambridge, MA, Cambridge University Press.

1985, "The Forum of Principle", in A Matter of Principle. Cambridge, MA, Harvard University Press.

— 1986, Law's Empire, Cambridge, MA, Harvard University Press.

FRANKFURT, H. 1971, "Freedom of the Will and the Concept of a Person", Journal of Philosophy 68: 5-20; repr. in The Inner Citadel.

FREEMAN, S. 1992, "Original Meaning, Democratic Interpretation, and the Constitution", Philosophy and Public Affairs 21, 3.

GOLDSWORTHY, J. 1997, "Originalism in Constitutional Interpretation”, Federal Law Review 25, 1. 
HART, H. L. A. 1961, The Concept of Law, Oxford, Clarendon Press.

MACKENZIE, C. and STOLJAR, N. 2000. "Introduction: Autonomy Refigured", in MACKENZIE and STOLJAR (eds.), Relational Autonomy. Feminist Essays on Autonomy, Agency and the Social Self, New York, Oxford University Press.

RAZ, J. 1998, “Disagreement in Politics”, American Journal of Jurisprudence 43, 25.

1986, The Morality of Freedom, Oxford, Oxford University Press.

Reaume, D. 2002, "Of Pigeonholes and Principles: A Reconsideration of Discrimination Law", Osgoode Hall Law Journal 40: 113.

SCAliA, A. 1997, A Matter of Interpretation, Princeton NJ, Princeton University Press.

Schauer, F. 1989, "Is the Common Law Law?", California Law Review 77, 455.

TAYLOR, J. S., "Introduction", Personal Autonomy: New Essays on Personal Autonomy and its Role in Contemporary Moral Philosophy, Cambridge, Cambridge University Press.

WALDRON, J. 2006, "The Core of the Argument Against Judicial Review", The Yale Law Journal 115, 1346.

1999a, Law and Disagreement, Oxford, Oxford University Press.

_ 1999b, The Dignity of Legislation, Cambridge, Cambridge University Press.

Waluchow, W. J. 2007, A Common Law Theory of Judicial Review. The Living Tree, Cambridge, Cambridge University Press.

1994, Inclusive Legal Positivism, Oxford, Oxford University Press. 